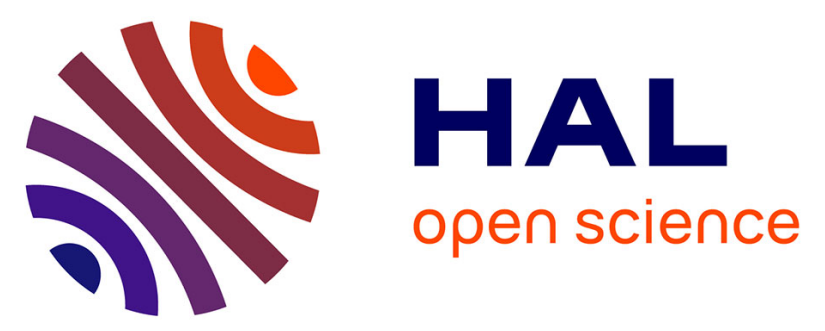

\title{
Development of an integrated generic model for multi-scale assessment of the impacts of agro-ecosystems on major ecosystem services in West Africa
}

Mahamadou Belem, Mehdi Saqalli

\section{- To cite this version:}

Mahamadou Belem, Mehdi Saqalli. Development of an integrated generic model for multi-scale assessment of the impacts of agro-ecosystems on major ecosystem services in West Africa. Journal of Environmental Management, 2017, 202, pp.117-125. 10.1016/j.jenvman.2017.07.018 . hal-01683535

HAL Id: hal-01683535

https://hal-univ-tlse2.archives-ouvertes.fr/hal-01683535

Submitted on 6 Sep 2018

HAL is a multi-disciplinary open access archive for the deposit and dissemination of scientific research documents, whether they are published or not. The documents may come from teaching and research institutions in France or abroad, or from public or private research centers.
L'archive ouverte pluridisciplinaire HAL, est destinée au dépôt et à la diffusion de documents scientifiques de niveau recherche, publiés ou non, émanant des établissements d'enseignement et de recherche français ou étrangers, des laboratoires publics ou privés. 
Research article

\title{
Development of an integrated generic model for multi-scale assessment of the impacts of agro-ecosystems on major ecosystem services in West Africa
}

\author{
Mahamadou Belem ${ }^{\text {a, }}$, Mehdi Saqalli ${ }^{\text {b }}$ \\ ${ }^{a}$ Complex System Modeling, West African Science Service Center on Climate Change and Adapted Land Use Competence Center, Burkina Faso \\ ${ }^{\mathrm{b}}$ UMR 5602 GEODE Géographie de l'Environnement, CNRS Université Toulouse 2 Jean Jaurès, 5, Allées Antonio Machado, 31058, Toulouse, France
}

\section{A R T I C L E I N F O}

\section{Article history:}

Received 26 October 2016

Received in revised form

14 April 2017

Accepted 7 July 2017

\section{Keywords:}

Climate change

Land use policy

Integrated assessment modeling

Coupled component model

\begin{abstract}
A B S T R A C T
This paper presents an integrated model assessing the impacts of climate change, agro-ecosystem and demographic transition patterns on major ecosystem services in West-Africa along a partial overview of economic aspects (poverty reduction, food self-sufficiency and income generation). The model is based on an agent-based model associated with a soil model and multi-scale spatial model. The resulting Model for West-Africa Agro-Ecosystem Integrated Assessment (MOWASIA) is ecologically generic, meaning it is designed for all sudano-sahelian environments but may then be used as an experimentation facility for testing different scenarios combining ecological and socioeconomic dimensions. A case study in Burkina Faso is examined to assess the environmental and economic performances of semi-continuous and continuous farming systems. Results show that the semi-continuous system using organic fertilizer and fallowing practices contribute better to environment preservation and food security than the more economically performant continuous system. In addition, this study showed that farmers heterogeneity could play an important role in agricultural policies planning and assessment. In addition, the results showed that MOWASIA is an effective tool for designing, analysing the impacts of agro-ecosystems.
\end{abstract}

(C) 2017 Published by Elsevier Ltd.

\section{Introduction}

Agriculture plays an important role in the economy of West African countries. In this region, the agricultural sector is the main provider of employment. More than $80 \%$ of the population is involved in agriculture and livestock; these two sectors contribute to $35 \%$ of the gross domestic product of these countries (Ben Mohamed et al., 2002). Moreover, 80\% of the food needs of the population depends on regional agricultural production (Ecowas, 2005). Two threats make it unlikely that this farming system may continue:

- West African countries have the highest population growth rates in the world, with a quasi-doubling of its population before 2050 (FAOSTAT). This will have a huge impact on the land

\footnotetext{
* Corresponding author. West African Science Service Centre on Climate Change and Adapted Land Use, 6 P.O. Box 9507, Ouagadougou 06, Burkina Faso.

E-mail addresses: belem.m@wascal.org, mahamadou.belem@gmail.com (M. Belem), mehdi.saqalli@univ-tlse2.fr (M. Saqalli).
}

availability per family (Saqalli et al., 2013). At the same time, sub-Saharan Africa (SSA) has the highest proportion of malnourished population (Hollinger and Staaz, 2015; Knox et al., 2012).

- Global warming impacts remain unclear with respect to rainfall levels but include more clearly higher rainfall variability, in an already extremely variable and vulnerable place (FAO, IFAD and WFP, 2015), is predicted for the future (Mougin et al., 2009). This situation increase drought risks during crucial growth periods. Land degradation (Abdoulaye and Lowenberg-DeBoer, 2000; Mortimore and Harris, 2005; Niemeijer and Mazzucato, 2002) and a lack of investment from governments and international institutions prevent the agricultural sector from reaching its full potential (Ecowas; Koning and Smaling, 2005).

Consequently, direct or indirect policies regarding climate adaptation and agriculture are urgently needed to alleviate rural poverty, food insecurity and negative environmental impacts associated with the agricultural sector. Developing such policies is a difficult task, as a wide range of policy sectors needs to be considered, including agriculture, the environment, forestry, water, 
energy as well as education, health and development (Stringer and Dougill, 2013). Moreover, the sustainability of potential policies needs to be assessed, which additionally requires integrating divergent stakeholders' (social actors and researchers) objectives (Hamilton et al., 2015) and considering multiple spatial and temporal scales (Veldkamp et al., 2001; Verburg et al., 2013), as well as cross-scale interactions (Stringer and Dougill, 2013). As a result, evaluating the future wellbeing of the rural population implies assessing the impacts of such policies on critically vital resources and ecosystem services provided by farming systems (Rosa and Sánchez, 2016).

Integrated Assessment Modeling (IAM) (Hamilton et al., 2015; Moretti et al., 2016) has proven to be an appropriate approach to provide and combine necessary information (Herrmann et al., 2011). IAM can help integrate knowledge and perspectives from different points of view (Delmotte et al., 2016; Hamilton et al., 2015; Voinov et al., 2016), provide an effective framework to formalize and simulate different scenarios, as well as to determine the potential impacts of decisions (Zessner et al., 2017), and explore interactions and feedbacks at different scales in the decision-making process (van Ittersum et al., 2008); (Bergez et al., 2013; Welsh et al., 2013). However, IAM present some flaws for now:

- Previous IAM failed to integrate the interactions between different scales without information distortion between scales, through aggregation/disaggregation processes (Castella et al., 2007; van Ittersum et al., 2008) (Jahel et al., 2016). Even more, most of these IAM are restricted to one scale and context (Belem et al., 2011; Castella et al., 2007; Jahel et al., 2016; van Ittersum et al., 2008) making these models site-specific and limiting their role in knowledge integration.

- IAM integrate socio-economic, biophysical and policy dimensions but without an explicit formalization of these dimensions and their interactions at different scales (Piorr et al., 2009; Sieber et al., 2008; van Ittersum et al., 2008), reducing thereby their genericity.

- Finally, farmers decision are simulated using optimization based on past and present data (Sieber et al., 2008; van Ittersum et al., 2008). Consequently these models are linear, unable to predict major shifts such as unexpected social changes or policy results (Malawska et al., 2014) and cannot deal with lack of data, though an important issue in West-Africa.

The objective of this research is to develop an integrated and multi-scale modeling and impact assessment approach for assessing the impacts of climate change (CC), agro-ecosystem and demographic transition along a partial overview of economic aspects (poverty reduction, food self-sufficiency and income generation) on major ecosystem services in West-Africa. In this study, we are concerned with the explicit separation between the different scales by distinguishing between (1) the decomposition of an agroecosystem into its social, economic, biophysical and politic components and (2) the decomposition of the environment into multispatial scales.

The resulting model, named West Africa Agro-Ecosystem Integrated Assessment (MOWASIA), is ecologically generic, meaning that it is designed for the Sudano-Sahelian environment but may also be used for experimentation purposes to test different scenarios combining ecological and socio-economic dimensions. The model is applied to explore the impacts of cropping and soil nutrient management systems on soil carbon, farm income and food security. This paper presents the materials and methods, describes the structure and architecture of MOWASIA. Major simulation outputs are presented and discussed, and future development potential is highlighted.

\section{Materials and methods}

\subsection{Integrated assessment modeling approach}

Land use presents us with a dilemma. On the one hand, many land-use practices are absolutely essential for humanity because they provide critical natural resources and ecosystem services, such as food, fiber, shelter, and freshwater. On the other hand, some types of land use degrade the ecosystems and services upon which we depend (Foley et al., 2005). We therefore aim to combine scenarios to explore how to optimally promote the provision of ecosystem services needed together with the question of acceptance, technological-economic feasibility and sustainability of potential future traits in land use planning and management. We also consider social aspects (poverty reduction and food security) and economic benefits (crop yields, income). These aspects call for the integration of knowledge from different disciplines (agronomy, geography, soil science, sociology, economy) to develop an integrated and deep understanding of agro-ecosystems. The modeling approach is this study is based on integrated assessment modeling (IAM).

Our approach in this study is based on the integration of processes and models to account for the social, economic, biophysical and policy issues at multiple spatio-temporal scales, as well as the integration of knowledge from different disciplines. Consequently, we used a coupled component modeling (CCM) approach (Bollinger et al., 2016; Drogoul et al., 2016). Indeed, various modeling approaches are commonly used for IAM, e.g., system dynamic (Forrester, 1961), Bayesian networks, CCM, agent-based models (Bousquet and Le Page, 2004; Villamor and van Noordwijk, 2016), knowledge-based models and fuzzy models (Suganthi et al., 2015). CCM is one of the most relevant modeling approaches to achieve IAM and knowledge integration from different disciplines. As coupled component models are able to combine any type of model, all types of applications are theoretically possible; depending on the model, we can include an integrated outcome and multi-scale simulation (Kelly et al., 2013). Using CCM allows us to explore feedbacks between the social, economic, biophysical and policy components of the system.

\subsection{Modeling procedure}

First, a general conceptual model was developed to provide a common representation of land use systems in West Africa using the general framework for analyzing the sustainability of socioecological systems (SES) developed by Ostrom (2009) (see the supplementary material). This general framework provides a unique framework for knowledge integration from different disciplines and stakeholders, as well as a common understanding of the complexity of the system while taking the social, economic, ecological and political dimensions into account. This framework is composed of four interacting subsystems: resource system, resource units, governance system and users.

This general conceptualization, which is appropriate at the global level for combining data, needs to address the differences between farming families: indeed, families are structurally different and act as rationally different entities. However, rural families interact, both directly (by family member exchanges through marriages, mutual support and trade of goods) and indirectly, through the land. This led us to rely on an agent-based model $(A B M)$ to represent the social dimension. In addition, to better represent the heterogeneity of families and their interactions, the ABM allows consideration of the impacts of individual family units on land use change and the way the policy makers impact family decision making. Indeed, in this study, we assume that the land use 
change is driven by decision making within a farming family unit. In addition, we assume that the objective of the policy makers is to change the behaviour of entities or individuals (Malawska et al., 2014). CaTMas (Belem et al., 2011), a generic ABM, was selected to represent farm family unit decision making regarding land uses, practices and the way the environment is impacted. CaTMAS simulates the dynamics of carbon resources at a village territory level in West African savannas. The model takes the following into account: 1) the heterogeneity of farming families differs due to their cropping system, organic and fertilizer management, resource endowment, farm size, social group and spatial location and 2) the interactions between crop production and livestock. The FarmDesign model (Groot et al., 2012) was selected to simulate farmers' decision making and resource allocation among their activities, according to the rationalities we define. FarmDesign is a bioeconomic model that simulates farmers' decision making and allows the design of a farming system in conjunction with stakeholders while taking account of various production and environmental objectives as well as farm and policy constraints. Integrating FarmDesign into MOWASIA represents the policy dimension of agro-ecosystems.

CatMas did not initially provide an explicit multi-scale spatial representation. Consequently, we developed an explicit spatial model to provide a multi-scale spatial organization of land management and biophysical dynamics (see section 2.4). The biophysical dynamics concern the soil-plant-atmosphere interactions simulated using the Century model (Parton et al., 1994). Century is a flexible model that represents the dynamics of different land use types: crop lands, grasslands, forests, savannas and irrigation systems.

The various models and modules were integrated through a component-based approach using utilities from the OpenMi (Gregersen et al., 2007) and Mimosa (Müller, 2004) platforms. The modules and models were encapsulated in autonomous components that were subsequently linked.

Finally, test case simulations were performed to show the ability of the model to handle the complexity of agro-ecosystems. For that, data have been used collected from different sources and integrated in a Postgres database (Table 1).

The main objective of the farmers is to increase their production to attain self-sufficiency; consequently, food security and income generation are the main drivers. However, a decrease in soil carbon, an important indicator of soil fertility, is one of the main constraints to agricultural production. The objective of the simulation was to assess the impacts of cropping systems and soil nutrient management on soil carbon and farmers' income and food security (for more details see section 2.5).

\subsection{Model development}

The architecture of MOWASIA consists of six modules: data management, climate, social, livestock management, biophysical and operating system modules.

\subsubsection{Data management module}

The data management module manages data access. A Postgres database is associated with this module. The database integrates data on household typology, animals, crop management, forest management, livestock management, and spatial variability of the soil, climate and vegetation.

\subsubsection{Climate module}

The climate module computes climate data according to the climate scenario. This module describes the spatio-temporal variability of the climate and decomposes the system into climate zones that spatially represent the same climate trends. Each climate zone is characterized by historical and predicted climate data for a specific period and scenario. In this study, monthly climate data were used.

\subsubsection{Social module}

The social module represents the social dynamics of the system. This module describes the heterogeneity of the families with respect to their decision making and their interactions. In the model, each family is characterized by a farm, a set of tools and assets for production, a cropping system, and a herd. A family may produce different crops according to different and combined rationalities (cash, crop).

The dynamics of the social module include the demography dynamics (birth, death, immigration, emigration) and the families' decision making with respect to crop, livestock management and food management (for more details see Belem et al. (2011)).

Families produce several crops to meet different needs (food and money). Depending on their needs, the cropping system, resource endowment (equipment, labor, manure, fertilizers), and crop yield, families allocate lands to different crops. The available labor is shared between different activities, e.g., crop production, livestock management and off-farm activities, and impacts crop production and the performance of other activities. Family members provide labor according to their age and gender.

Table 1

Sources of data.

\begin{tabular}{ll}
\hline $\begin{array}{l}\text { Crop and crop management data } \\
\text { Crop characteristics and yields } \\
\text { Cropping system }\end{array}$ & $\begin{array}{l}\text { Adapted from century database } \\
\text { (Youl, 2009) } \\
\text { Fertility use }\end{array}$ \\
$\begin{array}{l}\text { (Matlon and Fatchamps, 1988; Youl, 2009) } \\
\text { (Thiombiano, 2015) }\end{array}$ \\
$\begin{array}{l}\text { Biophysical data } \\
\text { Soil data }\end{array}$ & (Youl, 2009) \\
Household data & \\
Household typology & (Youl, 2009) \\
Household economy & (Youl, 2009) \\
Demographic data & (UNDP, 1999) \\
& (UNPP, 2005, 2006) \\
$\begin{array}{l}\text { Daily calories need } \\
\text { Animal data }\end{array}$ & FAO stat \\
Herd structure & (Landais and Guérin, 1992; Landais and Lhoste, 1993) \\
Feed requirement & (Schlecht et al., 2006; Schlecht et al., 2007) \\
Pastoral Dynamics & (Landais and Guérin, 1992; Landais and Lhoste, 1993) \\
Spatial data & (Landais and Guérin, 1992; Landais and Lhoste, 1993) \\
\hline
\end{tabular}


At the end of the rainy season, the crops are harvested and shared for different needs. A part of the production is stored for food, and the reminder is sold (see Belem et al. (2011) for a more detailed description).

The revenue of the families depends not only on the crop production but also on the off-farm income of the household.

The revenue generated is used to purchase food and to invest in tools and assets to improve crop production.

\subsubsection{The livestock management module}

Farmers in the model associate crop production to livestock. Each herd is characterized by its size and the individual animals in the herd. Each individual animal is characterized by its age, weight.

The dynamics of animal in model take account the whole cycle of production: birth, growing, selling and death. The growth of animal depends on their pastoral dynamics that is spatially represented. Animal uptakes biomass and excretes faces. Out of the production season, animals consumes crop residues and consequently contribute to soil fertilization through excretion.

Farmer sells animals if the crop production is not sufficient to cover the food and money need. In addition, farmer sells too old animals.

\subsubsection{Biophysical module}

The biophysical module represents the spatial variability of the soil and vegetation and simulates crop, tree and grass growth, as well as the soil-plant-atmosphere interactions. This module is represented as cellular automata. Each cell is characterized by a soil and vegetation type. The dynamics (soil dynamics, plant growth) of each cell are computed using the Century model as a sub-model.

The biophysical module dynamics concern the vegetation growth, run-off and soil dynamics. These dynamics are influenced by an individual's decision making in the socio-economic module. The land management actions (planting, cultivation, fertilization, tree removal, fire, grazing) in the socio-economic module are translated to the biophysical module as biophysical actions. Based on the different actions in each cell during a one-year simulation, the human decision-making impacts are simulated using the Century model.

\subsubsection{The operating system module}

The operating system links the socio-economic module to the biophysical module. Human actions are translated into biophysical action through the operating system. In addition, the operating system represents the land use change at different scales. It is an explicit multi-scale spatial model (cf. section 2.4).

\subsection{The spatial organization}

The multi-scale spatial representation is established on "region"-based, compartmental spatial models (Kelly et al., 2013). The dynamic coupling concept of a land change model (Moreira et al., 2009) was used to develop the spatial component of the model. In this concept, each spatial scale corresponds to a management level (country, region, watershed, village, farm) and is represented by an explicit spatial model. Consequently, one can use different models to represent the dynamics of land use at different scales. Each spatial scale is characterized by a set of spatial elements. A spatial element at an upper scale (father) is an aggregation of the spatial elements of the lower levels (children). The father influences the dynamics of the children and vice versa.

\subsection{Configuration of the simulations}

Simulations were performed to assess the effects of the settlement and development of a human community on the carbon cycle of a virgin territory of a sub-humid West African savanna in Burkina Faso (Fig. 1). Specifically, the objective of the simulations was to assess the impacts of two cropping systems, i.e., a semicontinuous system (SCS) and a continuous system (CS), on soil carbon and farmer livelihood. The SCS is based on a five-year rotation of yam (Dioscorea), maize, sorghum (Sorghum bicolor), sorghum, and sorghum followed by fifteen fallow years. The CS is based on a 5-year cycle starting with 3 years of sorghum, followed by maize and then cotton. The SCS and CS farm use two different fertilizer managements. Then, the SCS farm mainly rely the organic fertilizer while the SCS farm use the chemical fertilizer.

The population in the simulations comprised 200 households divided in two family types based on two different cropping systems:

1. Native, relying on the SCS (SCS farm). At $t=0$, the SCS farms had 17 family members, a 31-ha farm area and 26 livestock heads.

2. Migrant, using the CS (CS farm). At $\mathrm{t}=0$, the CS farms had 17 family members, a 15-ha farm area and 38 livestock heads.

Therefore, the simulations started with a population of 400 agents (200 family agents, each of which had one herd agent).

The soil characteristics corresponded to the major soil characteristics of the south-western region of Burkina Faso. Rainfall and temperature regimes were assumed to be those of Bobo-Dioulasso, Burkina Faso. The Rainfall data used in this simulation are the same as those used in Belem et al. (2011).

\section{Results}

\subsection{Farm environmental performance}

The simulation results showed that the two cropping systems had different impacts on the soil organic carbon (SOC). Specifically, there was a greater SOC decrease in the CS than in the SCS farms; i.e., $16 \%$ and $5 \%$, respectively, after 30 years of simulation (Fig. 2). The high level of SOC in the SCS farms is primarily due to the fallow practice (15 years) and the use of organic fertilizer, whereas the CS farms use mineral fertilizer, especially for cotton production, and do not practice fallowing. The use of organic fertilizer maintains soil temperature and contributes to carbon stock, whereas "mineral fertilizer can cause a decline in SOC" (Bationo et al., 2007). Most studies in Africa show that continuous cultivation using mineral fertilizers has increased nutrient leaching (Bationo et al., 2007), and cash crop-based farms tend to have a negative partial balance for certain soil nutrients at the farm level (Thiombiano, 2015).

The use of organic matter is an effective means to combat the negative effects of climate change on soil fertility decline and consequently, to combat food insecurity in regions of West Africa. However, the main challenge is the availability and quality of organic fertilizer. Insufficiency and difficulty in accessing organic fertilizer has led to an increase in mineral fertilizer use and inadequate management of soil fertility in West Africa. Therefore, policy makers should construct resilient farming systems in this region and support soil fertility improvement programs, e.g., through better access to organic fertilizer. In this respect, Thiombiano (2015) argued that "farm resilience arises from internal decision making and from external decision making through policies and intervention measures".

\subsection{Farm economic performance}

Analysis of per capita food and income production (see the supplementary material) in SCS and CS farms showed a disparity of 

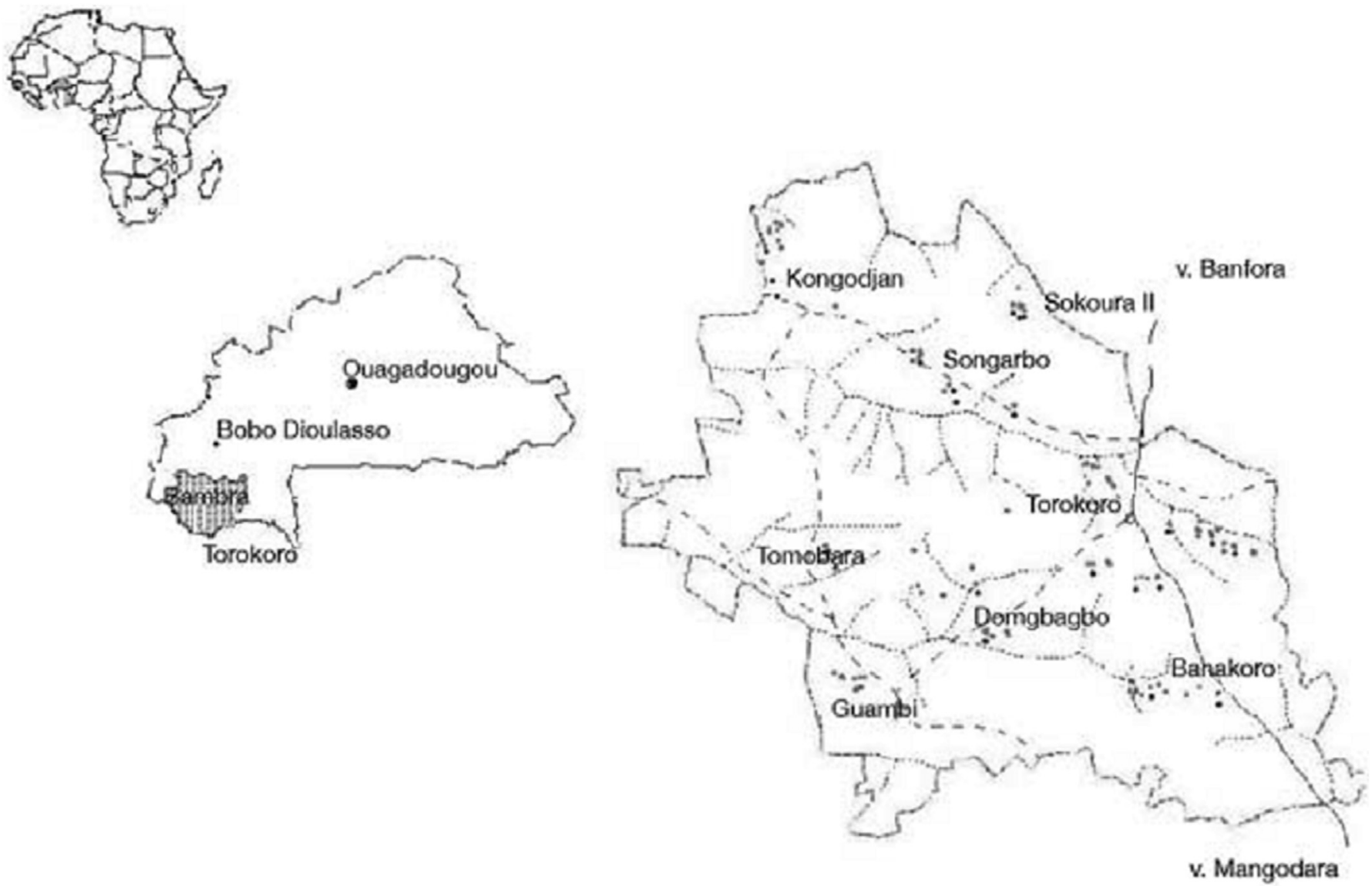

5 kilomètres

Fig. 1. Map of Torokoro village (Youl et al., 2008).

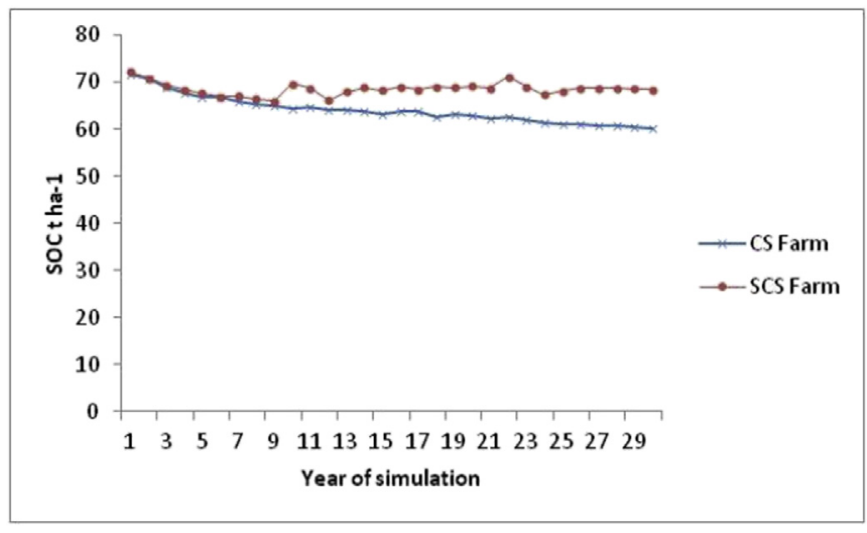

Fig. 2. SOC changes in different cropping systems.

SCS and CS cropping systems impacts on the farmers' livelihoods (Fig. 3). The annual food and cash income per capita from the CS farms was $706.10^{3} \mathrm{KCal}\left(1963.23 \mathrm{KCal} \mathrm{day}^{-1} \mathrm{capita}^{-1}\right)$ and 361 Euros year ${ }^{-1}$ compared with $906.10^{3} \mathrm{Kcal}^{\left(2518 \mathrm{kCal}_{\text {day }}{ }^{-1} \text { cap- }\right.}$ ita $^{-1}$ ) and 115 Euros year $^{-1}$, respectively, for the SCS farms. The SCS farms rely more on food crops (sorghum and yam) while the CS farms rely mainly on cash crops (cotton and maize). Consequently, food production is more important for the SCS farms, whereas the CS farms have higher income. However, with less than $\$ 1.90$ day $^{-1}$ capita $^{-1}$, these two farm types are below the poverty line.
The higher income of the CS farms can be explained by their intensification level and the use of mineral fertilizer. The CS farms are more intensive than the SCS farms; the cultivated area is 0.45 ha capita $^{-1}$ (CS farms) and 0.28 ha capita ${ }^{-1}$ (SCS farms) (Fig. 3). However, the CS farms are not sustainable in the long term. With a rapid decline in SOC, the soil fertility will decline over the long term and will negatively impact the economic performance of these farms.

\subsection{Land use and land cover change}

The simulation results showed an important land use and land cover change (Fig. 4). We observed that maize production increased while sorghum production decreased. Specifically, the maize production increased from an average of $21.58 \%-45 \%$ of the total crop land after 30 years of simulation. In the same period, the sorghum production decreased from an average of $44.29 \%-25.20 \%$ of the total crop land, and the land under yam decreased from $22.95 \%$ to $16.5 \%$.

The land use and land cover changes caused a decline in SOC (Fig. 5). SOC is an indicator of soil fertility, and a decline in SOC results in a decrease in crop yield, therefore impacting farm decision making. When crop yields decline and arable land is available, farmers increase the cultivated area to compensate for the loss of production and to achieve their objectives. Maize and cotton are more sensitive to soil fertility decline compared with sorghum and yam. This explains why the cultivated area under maize and cotton increased at the expense of sorghum and yam. 


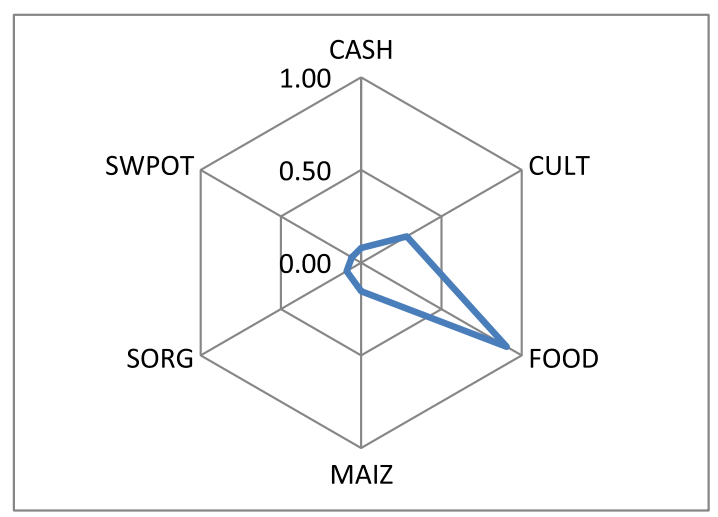

SCS Family

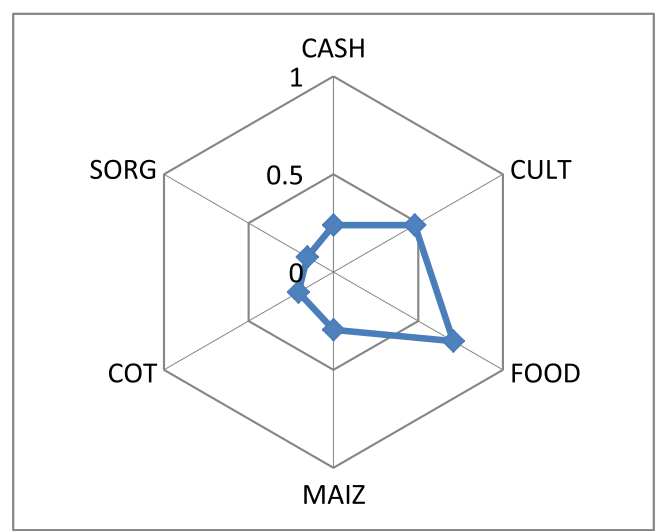

CS Family

Fig. 3. Characteristics of family types after 30 years of simulation.

\section{Discussion}

\subsection{Heterogeneity of farmers and sustainable development}

Based on the overall analysis, it can be stated that the heterogeneity of farming systems can play an important role in the sustainable development of developing countries and should be taken into account in the design of effective climate and agricultural policies. The objectives of policy makers are to achieve both socioeconomic and environmental development for sustainable development. In this regard, policy makers need to find a trade-off between these various objectives. There are numerous farmers in an agro-ecosystem; these farmers differ according to their socioeconomic characteristics (household size, farm area, resource endowment, relationships, crop use) and biophysical conditions (spatial location, soil fertility).

In addition, the activities of farmers do not result in the same environmental impacts, and farmers do not respond in the same way to environmental stress or the introduction of new technologies (Diarisso et al., 2015; Thiombiano, 2015).

Therefore, taking account of the heterogeneity of farmers could allow identification of a trade-off between the various policies. However, this calls for a systems approach. "The systems approach can, among other things, be used to assess the effect of interactions between farms on the overall environmental impact of the farming region" (Payraudeau and van der Werf, 2005). This study is based on a systems approach, and the ABM was used to represent the socio-economic context of the system.

\subsection{Modeling farmers decision making as driving forces of agro- ecosystem changes}

According to Malawska et al. (2014), the farmers' decision making are affected by factors that can be divided in five groups: agricultural and environment regulation, economic factors, physical condition, social factors and personal/psychological factors. For instance,

- Sociologically, the decision making at the level of the household strongly depends on family structure, which itself determine the level of multi-activity, the number of persons making decisions in the household, the variability of objectives (securization, maximization, patrimonial, food and cash, etc.) (Saqalli et al., 2013). This family structure is changing all the time. Deaths, marriages and births in the family influence the gender ratio and consequently the future family structure and labor availability. The family structure of the household is explicitly represented in the model. As Saqalli et al. (2013), we explicitly acknowledge that families drive multiple activities (agriculture, off-farm activities and livestock) to achieve multiple objectives.

- Ecologically, the household decision making is affected by the territory potentialities and affects in return the land use and the land cover, and thereby the environment. For instance, in the model the land allocation for crop production depends on crop yields depending on soil fertility and climate.

- In terms of decision making and rationality, in most existing integrated agro-ecosystem models, farmers decision making is optimization-based (Castella et al., 2007; Sieber et al., 2008; van Ittersum et al., 2008) and the land use and land cover change is represented by probabilistic transition rules (Castella et al., 2007; Jahel et al., 2016). These last authors used statistical approach to simulate the land use and land cover change based on the past and present data as in most existing agro-ecosystem models. Consequently these models cannot simulate the long term land use and land cover change. Depending on the past and present data, these models are hardly applicable in developing countries and particularly in West-Africa where lack of relevant data and difficulty of access to existing data is a huge problem. Land use and land cover change are driven by the household decision making. Farmers take decisions based on their socioeconomic characteristics (family size, labor needs, resources endowment) and their environmental conditions (soil, climate, crop yields). These factors change all the time and so the farmers practices. To consider such dynamics and other environmental dynamics, we postulate the inherent rationality of farmers. As said previously, such rationality is multi-objective meaning our model acknowledges the non-linearity of land use practices.

\subsection{Multi-scale simulation of agro-ecosystem}

The integrated model developed in this study provides an explicit multi-scale representation of agro-ecosystem. The model simulates the interactions between and within scales, i.e. plots, family farms, village territories and sub-climatic zone and regional scales. Each scale is represented as an autonomous component/ entity (or model) encompassing its own dynamics and interacting for information exchange with the other components of the model. 

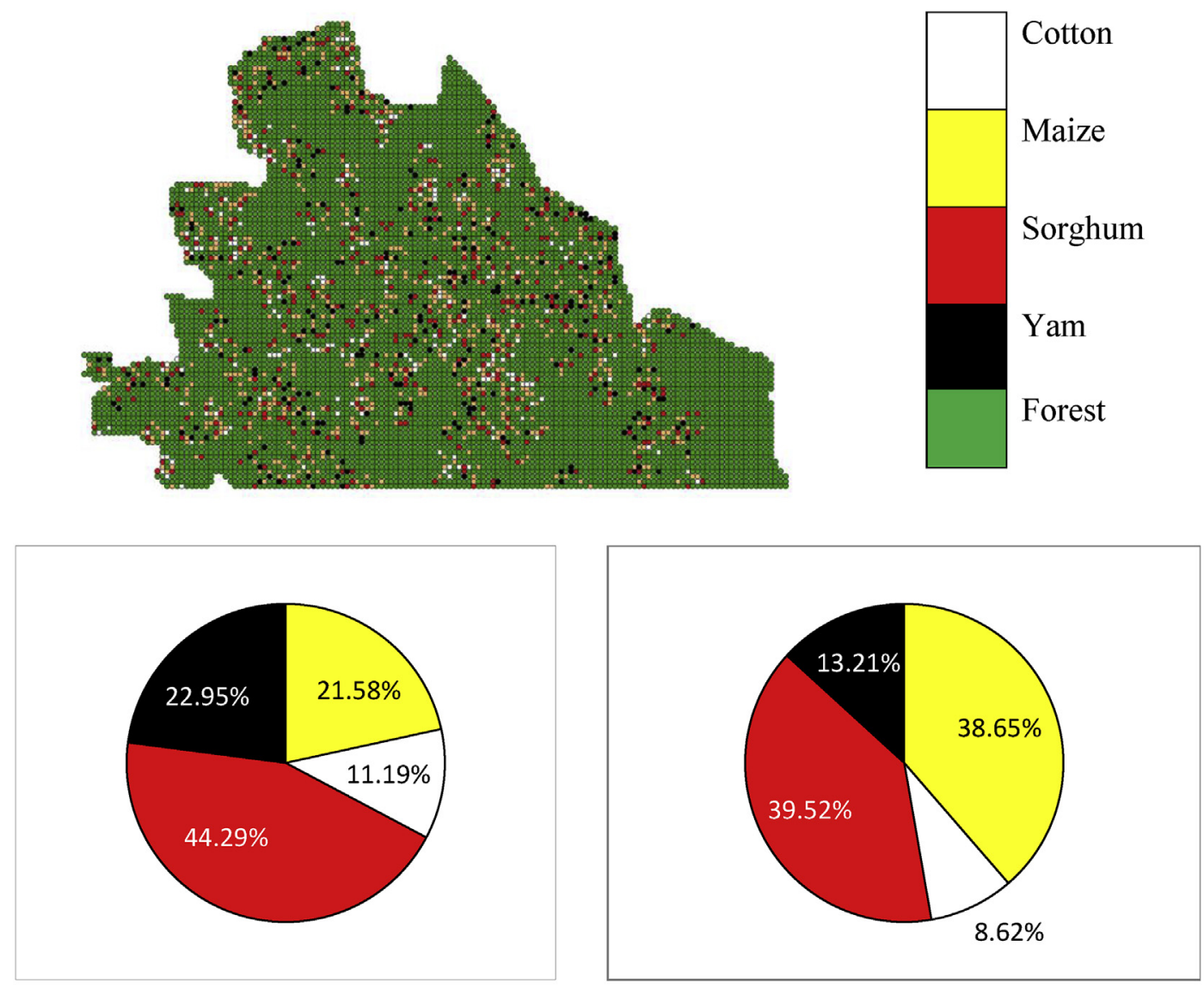

After 5 years

After 10 years

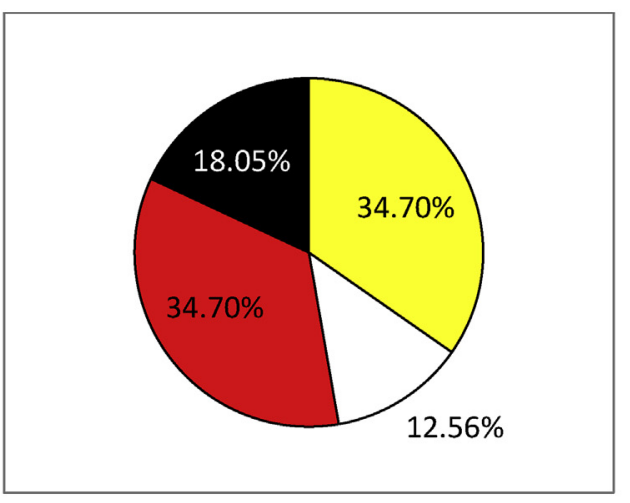

After 20 years

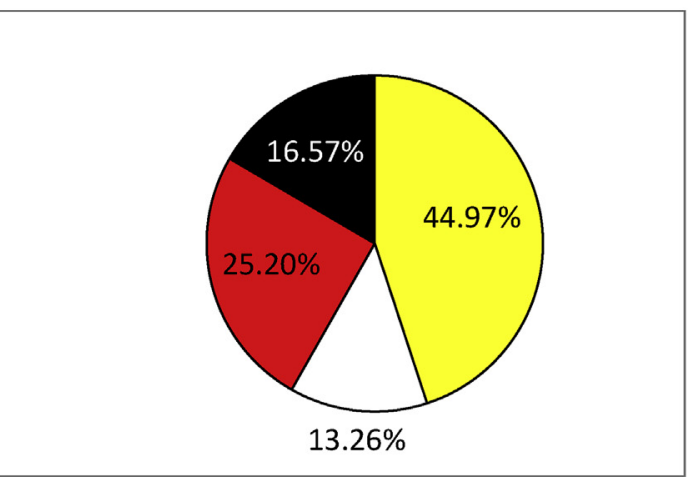

After 30 years

Fig. 4. Land use and land cover change.

This approach provides flexibility and reuse of the model structure and avoids aggregation and disaggregation of information between scales which cause information distortion (Jahel et al., 2016).

The multi-scale spatial simulation of agro-ecosystem is not new:

The Seamless (Sieber et al., 2008; van Ittersum et al., 2008) framework takes in account the interactions from field to farm and region scales. However, the interactions between farm and region scales in these models are based on aggregation and disaggregation of information. In addition, Seamless is constraint to the regional scale: Europe.
CatMAS (Belem et al., 2011) considers these interactions between plot, farm and village territory levels. However, the farm level is not explicitly represented. CatMAS (Belem et al., 2011) is restricted to the territory village scale. There is no possibility to remove scale in CatMas. Farm remains an aggregation of plot and the dynamics at the system level is the aggregation of information from the farms. In Jahel et al. (2016) although one can add new scale, the existing scales cannot be removed.

From a multi-scale point of view, our approach is closed to the one developed by Jahel et al. (2016). However, our model uses the 


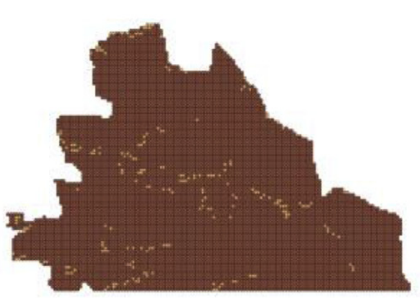

5 years

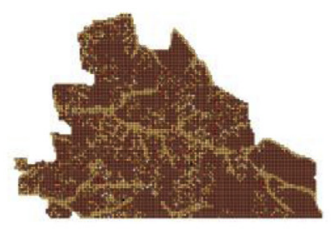

20 years
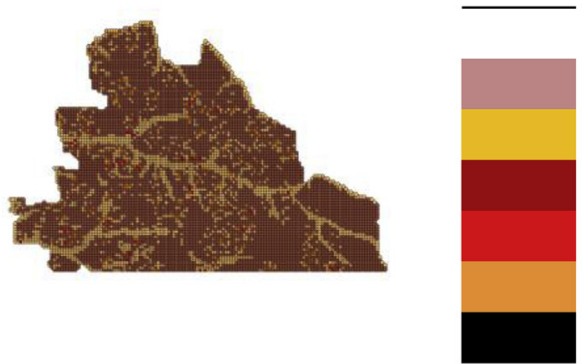

$0-20$ tha $^{-1}$

$20-40$ t ha $^{-1}$

$40-60$ tha $^{-1}$

$60-80$ tha $^{-1}$

$80-100$ tha $^{-1}$

$100-120$ tha $^{-1}$

120-140 tha $^{-1}$
10 years

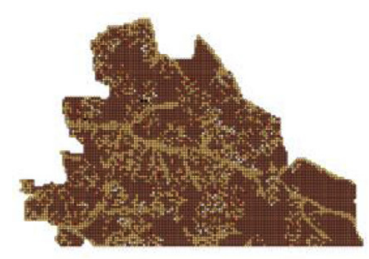

30 years

Fig. 5. The spatial repartition of SOC.

component based approach to represent concretely and separately the various scales (plot, farm, village territory, sub-climatic zone or region).

In the component-based simulation, the simulations are viewed as a collection of components that interact with each other by exchanging messages (Chen and Szymanski, 2001). Each component type can be used to represent different situations using different initial parameters. In our case, the different components can be instantiated several times to generate multi-sites and to conduct a regional simulation.

Consequently, the structure of our model is not constraint to one scale and is fully generic in terms of agro-ecology but again still limited to the context of West-Africa. The combination of explicit multi-scale and component-based simulation allows extending the structure of the model to come up with multi-contexts (multivillage, multi-regions) simulations.

In addition to allow multi-scale explicit representation of agroecosystem, the component-based simulation approach used in this study allowed to represent explicitly the different dimensions (social, economic, biophysical and policy) at different scales. This approach allows representing explicitly the feedbacks loops between the different dimensions and to provide a good representation and simulation of agro-ecosystems observed in the study area.

\section{Conclusion}

In this study, we proposed a solution to improve modeling for agricultural policy design in West Africa while taking the social, economic, biophysical and policy dimensions into account.

This was based on a component-coupling modeling approach, including different types of models, to account for the socioeconomic, biophysical and policy dimensions of agro-ecosystems in West Africa. A case study in Burkina Faso was examined to assess the environmental and economic performances of semicontinuous and continuous cropping systems. The simulations showed that the semi-continuous system, based on organic fertilizer use and fallow practice, contributed more to environmental preservation and food security compared with the continuous system. In addition, the simulations showed that the heterogeneity of farmers can play an important role in the planning and assessment of agricultural policies.

From the methodological point of view, this study showed that component-based simulation provides an effective way for explicit multi-scale and multi-dimensional simulation of agro-ecosystem. In addition, the drivers of agro-ecosystem considered in the current study showed that MOWASIA is a relevant tool for integrated assessment model of climate change and agricultural policies impacts in West-Africa.

In future studies, the model will be improved by integrating crop and tree models. In addition, hydrological model will be integrated to take account the impacts of land use and management on hydrological dynamics. Finally, the model will be validated and tested on real situations at the regional scale.

\section{Acknowledgments}

This work was funded by the German Federal Ministry of Education and Research (BMBF) through the West African Science Service Center on Climate Change and Adapted Land Use (WASCAL). The authors wish to appreciate the efforts of Nadine Andrieu and numerous anonymous reviewers whose comments and criticisms assisted in improving the quality of this manuscript to make it worthy of publication.

\section{Appendix A. Supplementary data}

Supplementary data related to this article can be found at http:// dx.doi.org/10.1016/j.jenvman.2017.07.018.

\section{References}

Abdoulaye, T., Lowenberg-DeBoer, J., 2000. Intensification of Sahelian farming systems: evidence from Niger. Agric.Agric. Syst. 64, 67-81.

Authro, 2005. Regional Agricultural Policy for West Africa: ECOWAP.

Bationo, A., Kihara, J., Vanlauve, B., Waswa, B., Kimetu, J., 2007. Soil organic carbon dynamics, functions and management in West African agro-ecosystems. Agric.Agric. Syst. 94, 13-25.

Belem, M., Manlay, R.J., Müller, J.P., Chotte, J.-L., 2011. CaTMAS: a multi-agents model for the simulation of carbon resources dynamics of West African villages. Ecol. 
Mod. 222, 3651-3661.

Ben Mohamed, A., van Duivenbooden, N., Abdoussallam, S., 2002. Impact of climate change on agricultural production in the sahel - Part 1. Methodological approach and case study for millet in Niger. Clim. Change 54, 327-348.

Bergez, J.-E., Charbrier, P., Gary, C., Jeuffroy, M.H., Makowski, D., Quesnel, G. Ramat, E., Raynal, H., Rousse, N., Wallach, D., Debaeke, P., Durand, P., Duru, M., Dury, J., Faverdin, P., Gascuel-Odoux, C., Garcia, F., 2013. An open platform to build, evaluate and simulate integrated models of farming and agro-ecosystemsq. Environ. Model Softw. 39, 39-49.

Bollinger, L.A., Nikolić, I., Davis, C.B., Dijkema, G.P.J., 2016. Multimodel ecologies: cultivating model ecosystems in industrial ecology. J. Indus. Ecol. 19, 252-263.

Bousquet, F., Le Page, C., 2004. Multi-agent simulations and ecosystem management a review. Ecol. Mod. 176, 313-332.

Castella, J.C., Kamb, S.P., Quang, D.D., Verburg, P.H., Hoanh, C.T., 2007. Combining top-down and bottom-up modelling approaches of land use/cover change to support public policies: application to sustainable management of natural resources in northern Vietnam. Land Use Policy 24, 531-545.

Chen, G., Szymanski, B.K., 2001. Component-based simulation. In: Kerckhoffs, E.J.H., Snorek, M. (Eds.), Mdeoling and Simulation Conference, Prague, Czech Republic.

Delmotte, S., Couderc, V., Mouret, J.-C., Lopez-Ridaura, S., Barbier, J-M. Hossard, L, 2016. From stakeholders narratives to modelling plausible future agricultural systems. Integrated assessment of scenarios for Camargue, Southern France. Eur. J. Agron. 82, 292-307.

Diarisso, T., Corbeels, M., Andrieu, N., Djamen, P., Tittonell, P., 2015. Biomass transfers and nutrient budgets of the agro-pastoral systems in a village territory in south-western Burkina Faso. Nutr. Cycl. Agroecosyst. 101, 295-315.

Drogoul, A., Huynh, N.Q., Truong, Q.C., 2016. Coupling environmental, social and economic models to understand land-use change dynamics in the mekong delta. Front. Environ. Sci. 4.

Foley, J.A., et al., 2005. Global consequences of land use. Science 309, 570.

Forrester, J.W., 1961. Industrial Dynamics. The MIT Press, Cambridge Massachusetts.

Gregersen, J.B., Gijsbers, P.J.A., Westen, S.J.P., 2007. OpenMI: open modelling interface. J. Hydroinform. 9, 175-191.

Groot, J.C.J., Oomen, G.J.M., Rossing, W.A.H., 2012. Multi-objective optimization and design of farming systems. Agric.Agric. Syst. 110, 63-77.

FAO, IFAD and WFP, 2015. The state of food insecurity in the world 2015. In: Meeting the 2015 international hunger targets: taking stock of uneven progress. FAO, Rome. ISBN 979-92-5-108785-5 (Assessed December, 2016).

Hamilton, S.H., ElSawah, S., Guillaume, J.H.A., Jakeman, A.J., Pierce, S.A., 2015. Integrated assessment and modelling: overview and synthesis of salient dimensions. Environ. Model Softw. 64, 215-229.

Herrmann, S., Van de Fliert, E., Alkan-Olsson, J., 2011. Editorial: integrated assessment of agricultural sustainability: exploring the use of models in stakeholder processes. Int. J. Agric. Sust. 9, 293-296.

Hollinger, F., Staaz, J.M., 2015. Agricultural Growth in West Africa: Market and Policy Drivers.

Jahel, C., Baron, C., Vall, E., Karambiri, M., Castets, M., Coulibaly, K., Bégué, A., Lo Seen, D., 2016. Spatial modelling of agro-ecosystem dynamics across scales: case in the cotton region of West-Burkina Faso. Agric.Agric. Syst.

Kelly, R.A., Jakeman, A., Barreteau, O., 2013. Selecting among five common modelling approaches for integrated environmental assessment and management. Environ. Mol. Mutagen 47, 159-181.

Knox, J., Hess, T., Daccache, A., Wheeler, T., 2012. Climate change impacts on crop productivity in Africa and South Asia. Environ. Res. Lett. 7, 034032.

Koning, N., Smaling, E., 2005. Environmental crisis or 'lie of the land'? The debate on soil degradation in Africa. Land Use Policy 22, 3-11.

Landais, E., Guérin, H., 1992. Système d'élevage et transferts de fertilité dans la zone des savanes africaines. Cahiers Agric. 1, 225-238.

Landais, E., Lhoste, P., 1993. Système d'élevage et transferts de fertilité dans la zone des savanes africaines. Cahiers Agric. 2, 9-25.

Matlon, P.J., Fatchamps, M., 1988. Crop Budgets for Three Agroclimatic Zones of the West African Semi-Arid Tropics. IGRISAT.

Malawska, A., Topping, C.J., Nielsen, H.O., 2014. Why do we need to integrate farmer decision-making and wildlife models for policy evaluation? Land Use Policy 38 $732-740$

Moreira, E., Costa, S., Aguiar, A.P., Câmara, G., Carneiro, T., 2009. Dynamical coupling of multiscale land change models. Landsc. Ecol. 24, 1183-1194.

Moretti, M., De Boni, A., Roma, R., Fracchiolla, M., Van Passel, S., 2016. Integrated assessment of agro-ecological systems: the case study of the "Alta Murgia" National park in Italy. Agric.Agric. Syst. 144, 144-155.

Mortimore, M., Harris, F.M.A., 2005. Do small farmers' achievements contradict the nutrient depletion scenarios for Africa? Land Use Policy 22.

Müller, J.P., 2004. The Mimosa Generic Modelling and Simulation Platform. ABS'04, Lisbonne.

Niemeijer, D., Mazzucato, V., 2002. Environment 44, 20-31., 2002. Soil degradation in the West African Sahel: how serious is it? Environment 44, 20-31.
Ostrom, E., 2009. A general framework fro analyzing sustainability of socioecological system. Science 325.

Parton, W.J., Woomer, P.L., Martin, A., 1994. Modelling soil organic matter dynamics and plant productivity in tropical ecosystems. In: Woomer, P.L., Swift, M.J. (Eds.), The Biological Management of Tropical Soil Fertility. John Wiley \& Sons, Chichester, pp. 171-188.

Payraudeau, S., van der Werf, H.M.G., 2005. Environmental impact assessment for a farming region: a review of methods. Agric. Ecosyst. Environ. 107, 1-19.

Piorr, A., Ungaro, F., Ciancaglini, A., Happe, K., Sahrbacher, A., Sattler, C., Uthes, S., Zander, P., 2009. Integrated assessment of future CAP policies: land use changes, spatial patterns and targeting. Environ. Sci. Policy 12, 1122-1136.

Rosa, J.C.S., Sánchez, L.E., 2016. Advances and challenges of incorporating ecosystem services into impact assessment. J. Environ. Manag. 180, 485-492.

Saqalli, M., Bielders, C.L., Defourny, P., Gérard, B., 2013. Reconstituting family transitions of Sahelian western Niger 1950-2000: an agent-based modelling approach in a low data context. Cybergeo 634.

Schlecht, E., Hiernaux, P., Kadaouré, I., Lsebusch, C.H., Mahler, F., 2006. A spatiotemporal analysis of forage availability and grazing and excretion behaviour of herded and free grazing cattle, sheep and goats in Western Niger. Agric. Ecosyst. Environ. 113, 226-242.

Schlecht, E., Richter, H., Fernandez-Rivera, S., Becker, K., 2007. Gastrointestinal passage of Sahelian roughages in cattle, sheep and goats, and implications for livestock-mediated nutrient transfers. Anim. Feed Sci. Technol. 137, 93-114.

Sieber, S., Müller, K., Verweij, P., Haraldsson, H., Fricke, K., Pacini, C., Tscherning, K. Helming, K., Jansson, T., 2008. Transfer into decision support: the sustainability impact assessment tool (SIAT). In: Helming, K., Pérez-Soba, M., Tabbush, P. (Eds.), Sustainability Impact Assessment of Land Use Changes. Springer Berlin Heidelberg, pp. 107-128.

Stringer, L., Dougill, A., 2013. Channelling science into policy: enabling best practices from research on land degradation and sustainable land management in dryland Africa. J. Environ. Manag. 114, 328-335.

Suganthi, L., Iniyan, S., Samuel, A.A., 2015. Applications of fuzzy logic in renewable energy systems - a review. Renew. Sustain. Energy Rev. 48, 585-607.

Thiombiano, B. A. 2015. Exploring Soil Nutrient Management and Production Performances to Support Building Smallholder Farms' Resilience to Climate Change: Case of South-western Burkina Faso, Department of Civil Engineering, College of Engineering. Kwame Nkrumah University of science and Technology, KUMASI.

UNDP, 1999. Human Development Report. United Nations Development Program, New York, p. 262.

van Ittersum, M.K., Ewert, F. Heckelei, T., Wery, J., Alkan Olsson, J., Andersen, E. Bezlepkina, I., Brouwer, F., Donatelli, M., Flichman, G., Olsson, L., Rizzoli, A.E., van der Wal, T., Wien, J.E., Wolf, J., 2008. Integrated assessment of agricultural systems - a component-based framework for the European Union (SEAMLESS). Agric.Agric. Syst. 96, 150-165.

UNPP, 2005. World Urbanization Prospects: The 2005 Revision.

UNPP, 2006. Population Division of the Department of Economic and Social Affairs of the United Nations Secretariat. In: World Population Prospects: The 2006 Revision.

Veldkamp, A., Kok, K., De Koning, G.H.J., Schoorl, J.M., Sonneveld, M.P.W., Verburg, P.H., 2001. Multi-scale system approaches in agronomic research at the landscape level. Soil Tillage Res. 58, 129-140.

Verburg, P.H., Mertz, O., Erb, K.-H., Haberl, H., Wu, W., 2013. Land system change and food security: towards multi-scale land system solutions. Curr. Opin. Environ. Sustain. 5, 494-502.

Villamor, G.B., van Noordwijk, M., 2016. Gender specific land-use decisions and implications for ecosystem services in semi-matrilineal Sumatra. Glob. Environ. Chang. 39, 69-80.

Voinov, A., Kolagani, N., McCall, M.K., Glynn, P.D., Kragt, M.E., Ostermann, F.O., Pierce, S.A., Ramu, P., 2016. Modelling with stakeholders - next generation. Environ. Model Softw. 77, 196-220.

Welsh, W.D., Vaze, J., Dutta, D., Rassam, D., Rahman, J.M., Jolly, I.D., Wallbrink, P., Podger, G.M., Bethune, M., Hardy, M.J., Teng, J., Lerat, J., 2013. An integrated modelling framework for regulated river systems. Environ. Model Softw. 39, $81-102$

Youl, S., 2009. Dynamique et modélisation de la dynamique dans un agrosystème de savane de l'ouest du Burkina Faso. Institut de Développement Rural (IDR). Université Polytechinique de Bobo-Dioulasso, Bobo-Dioulasso.

Youl, S., Barbier, B., Moulin, C.H., Manlay, R.J., Botoni, H.E., Masse, D., Victor, H., Feller, C., 2008. Modélisation empirique des principaux déterminants socioéconomiques de la gestion des exploitations agricoles au Sud-Ouest du Burkina Faso. Biotechnol. Agron. Soc. Environ. 12, 9-21.

Zessner, M., Schönhart, M., Parajka, J., Trautvetter, H., Mitter, H., Kirchner, M., Hepp, G., Blaschke, A., Strenn, B., Schmid, E., 2017. A novel integrated modelling framework to assess the impacts of climate and socio-economic drivers on land use and water quality. Sci. Total Environ. 579, 1137-1151. 